\title{
ANALISIS PEMANFAATAN, FAKTOR PENDUKUNG DAN PENGHAMBAT, SERTA UPAYA OPTIMALISASI APLIKASI ZOTERO DALAM PENULISAN KARYA ILMIAH
}

\author{
Abdul Haliq ${ }^{1}$, Akmal Hamsa ${ }^{2}$, Sakaria $^{3}$ \\ ${ }^{1,2,3}$ Pendidikan Bahasa dan Sastra Indonesia, Universitas Negeri Makassar \\ Jalan Malengkeri, Kampus Parangtambung, Kota Makassar, Sulawesi Selatan \\ 'e-mail: abdul.haliq@unm.ac.id
}

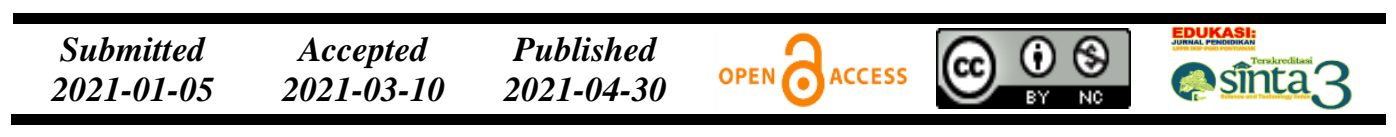

\begin{abstract}
Abstrak
Penelitian bertujuan untuk menganalisis pemanfaatan, faktor penghambat dan pendukung, serta upaya optimalisasi aplikasi Zotero dalam mengelola referensi karya tulis ilmiah. Penelitian menggunakan pendekatan kualitatif dan dilakukan pada mahasiswa Program Studi Pendidikan Bahasa dan Sastra, Universitas Negeri Makassar dengan jumlah 40 orang. Pengumpulan data menggunakan teknik observasi, angket, dan wawancara. Analisis data mengadopsi model analisis interaktif yang terdiri atas empat alur kegiatan, yaitu pengumpulan, reduksi, penyajian data, dan penarikan kesimpulan. Hasil penelitian menunjukkan bahwa pemanfaatan aplikasi Zotero memudahkan dalam mengelola referensi, memiliki perpustakaan digital, kemudahan sitasi tulisan, dan efisien. Adapun faktor penghambat yaitu mahasiswa tidak terbiasa menggunakan aplikasi, proses instalasi, sinkronisasi file, integrasi, dan penambahan sitasi dengan Microsoft Word. Sedangkan faktor pendukung yaitu keterampilan mengoperasikan komputer, penguasaan teknik penulisan makalah, aplikasi Zotero bersifat nonkomersial, kemudahan menyimpan, mengonversi, dan mengedit metadata. Upaya optimalisasi dilakukan dengan memberikan fasilitas pendukung seperti buku panduan dan video tutorial, buku panduan sitasi, serta WhatsApp group.
\end{abstract}

Kata Kunci: pemanfaatan Zotero: faktor penghambat dan pendukung; optimalisasi Zotero; referensi karya tulis ilmiah.

\begin{abstract}
This research aimed to analyze the utilization, inhibiting and supporting factors, and the efforts to optimize the Zotero application in managing references to scientific papers. This research used a qualitative approach and was conducted on 40 students of the Language and Literature Education Study Program, Universitas Negeri Makassar. Data collection was carried out by observation, questionnaire, and interview techniques. Data analysis was carried out by adopting an interactive analysis model consisting of four activity streams, namely data collection, reduction, presentation, and drawing conclusions. The results showed that the use of the Zotero application made it easier to manage references, have a digital library, ease writing citation, and efficient. The inhibiting factors including students are not accustomed to using applications, the installation process, synchronizing files, integrating, and adding citations to Microsoft Word. Supporting factors, including computer skills, mastery of paper writing techniques, noncommercial Zotero applications, ease of storing, converting, and editing metadata. Optimization efforts are carried out by providing guidebooks-video tutorials, citation manuals, and WhatsApp groups.
\end{abstract}

Keywords: use of Zotero; inhibiting and supporting factors; optimization of Zotero; references to scientific papers. 
Edukasi: Jurnal Pendidikan, Volume 19 Nomor 1 Tahun 2021

Analisis Pemanfaatan, Faktor Pendukung dan Penghambat.......

Abdul Haliq, Akmal Hamsa, Sakaria

Halaman 16-30

\section{PENDAHULUAN}

Mahasiswa dituntut untuk mampu menghasilkan karya tulis ilmiah sebelum menyelesaikan studi di perguruan tinggi. Tuntutan tersebut mengharuskan dosen membuat pembelajaran karya tulis ilmiah yang inovatif, sehingga pembelajaran dapat berjalan dengan kondusif dan efektif (Maryatun, 2020; Mansyur, 2016). Bentuk inovasi pembelajaran dapat dilakukan dengan berbagai cara, seperti menggunakan teknologi digital dalam proses pembelajaran. Pelaksanaan pembelajaran menulis karya ilmiah dengan memanfaatkan berbagai teknologi digital sangat dibutuhkan agar proses pembelajaran lebih variatif dan menghasilkan tulisan yang berkualitas.

Penggunaan teknologi digital adalah salah satu solusi yang dapat diterapkan dalam pembelajaran menulis karya ilmiah untuk membantu mahasiswa dalam mengelola tulisannya (Mauludin \& Cahyani, 2018). Berbagai perangkat lunak digital telah banyak dikembangkan untuk membantu dalam kegiatan menulis, seperti manajemen referensi (reference manager). Perangkat lunak reference manager dapat membantu seseorang untuk mengelola dan mencari berbagai referensi digital (Marshall, 2020; Ray \& Ramesh, 2017). Salah satu aplikasi manajemen referensi yang banyak digunakan dan tersedia secara gratis yaitu aplikasi Zotero. Aplikasi Zotero merupakan aplikasi manajemen referensi berbasis open source yang dapat digunakan untuk mencari, mengumpulkan, melakukan sitasi, dan berbagi tulisan atau hasil riset yang dilakukan secara online (Aidid et al., 2020; Winslow et al., 2016). Kegunaan aplikasi Zotero sangat membantu dalam mengelola tulisan ilmiah khususnya dalam mencari, mengumpulkan, dan melakukan sitasi referensi untuk digunakan dalam pengembangan tulisan ilmiah.

Penggunaan referensi ilmiah seperti buku, artikel jurnal, atau hasil penelitian dapat digunakan untuk mengembangkan tulisan ilmiah (Supriyanto \& Iswandari, 2017). Pengutipan referensi yang baik dapat menghindarkan penulis dari tindakan plagiarisme, sebaliknya pengutipan referensi yang buruk dapat berdampak terhadap tindakan plagiarisme (Thomas, 2017; Pecorari, 2013). Pentingnya mengutip dan mengatur referensi tulisan ilmiah menjadi salah satu bagian penting dalam pembelajaran menulis karya ilmiah, karena: (1) Untuk 
menghindari penjiplakan atau plagiarisme; (2) Untuk memberikan penghargaan pada penulis yang dikutip; dan (3) Untuk memudahkan pembaca menelusuri sumber-sumber kutipan yang digunakan dalam tulisan ilmiah (Kurniadi, 2017). Penulisan sumber rujukan atau daftar pustaka dapat meningkatkan kepercayaan pembaca terhadap ide atau gagasan yang disampaikan oleh penulis. Pembelajaran menulis ilmiah harus mampu memberikan mahasiswa kemudahan-kemudahan untuk mencari, mengumpulkan, mengatur, dan menggunakan referensi ilmiah melalui penggunaan aplikasi Zotero untuk memudahkan penulisan ilmiah.

Keuntungan menggunakan aplikasi Zotero yaitu dapat digunakan untuk mengumpulkan, mengorganisasi, melakukan sitasi, dan berbagi hasil riset (Aidid et al., 2020). Aplikasi Zotero dapat menghimpun berbagai referensi yang bersumber dari buku, artikel ilmiah, jurnal, koran, majalah, dan lain sebagainya yang tersedia secara online dalam bentuk atau format .pdf (Supriyatno, 2018). Namun demikian, banyaknya referensi yang tersedia secara online menuntut seseorang untuk mampu membedakan dan mengurutkan referensi yang valid dan yang tidak (Haliq \& Riyanti, 2018). Sehingga, setiap orang harus mampu menilai referensi yang dikumpulkan dan dapat digunakan sebagai referensi dalam penulisan karya ilmiah.

Hasil observasi awal yang dilakukan oleh peneliti pada pembelajaran menulis karya ilmiah mahasiswa semester IV menunjukkan beberapa permasalahan mahasiswa dalam menulis karya ilmiah, khususnya terkait dengan pelanggaran hak cipta. Masalah yang dihadapi mahasiswa yaitu pengetahuan mahasiswa mengenai tata cara pengutipan dan penulisan sumber referensi yang digunakan masih minim. Hal tersebut didukung oleh data yang diperoleh peneliti setelah memeriksa hasil karya tulis mahasiswa menunjukkan bahwa karya tulis ilmiah mahasiswa berupa makalah masih ditemukan hasil plagiasi. Dari 30 makalah yang diperiksa oleh peneliti, ditemukan hasil plagiasi pada hampir semua karya mahasiswa, yakni 28 makalah (93,33\%). Bentuk plagiasi yang dilakukan oleh mahasiswa adalah tidak adanya pencantuman sumber-sumber yang dikutip. Mahasiswa juga belum memahami teknik penulisan kutipan dengan benar apabila mencantumkan ide, gagasan, atau hasil penelitian orang lain. Dari hasil observasi 
Edukasi: Jurnal Pendidikan, Volume 19 Nomor 1 Tahun 2021

Analisis Pemanfaatan, Faktor Pendukung dan Penghambat.......

Abdul Haliq, Akmal Hamsa, Sakaria

Halaman 16-30

juga ditemukan mahasiswa kurang kreatif untuk memanfaatkan aplikasi manajemen referensi karya ilmiah, meskipun telah tersedia aplikasi manajemen referensi yang bisa diunduh gratis di internet salah satunya adalah aplikasi Zotero.

Zotero merupakan aplikasi manajemen referensi yang tersedia secara gratis di internet dan dapat dioperasikan pada berbagai platform, seperti Microsoft Windows, Apple MacOS, maupun Linux (Courraud, 2014). Zotero sangat bermanfaat di setiap tahap pengutipan sumber, mulai dari mencari atau menelusuri referensi secara online, hingga penulisan dokumen yang berupa karya ilmiah (Courraud, 2014). Aplikasi Zotero dapat menyimpan berbagai file referensi seperti artikel jurnal, buku, makalah, skripsi, dan karya tulis ilmiah yang lain dalam bentuk perpustakaan pada aplikasi tersebut. Mahasiswa dapat membuat perpustakaan pribadi pada aplikasi Zotero, sehingga mempermudah mahasiswa dalam menelusuri kembali referensi yang telah dikumpulkan.

Beberapa penelitian telah dilakukan terkait dengan pemanfaatan aplikasi Zotero dalam mengelola referensi karya ilmiah. Penggunaan aplikasi Zotero membantu penulis dalam mengumpulkan, mengatur, dan mengutip berbagi sumber daya dengan mudah (Aidid et al., 2020; Idri, 2015). Aplikasi Zotero juga menjadi pilihan yang solutif bagi mahasiswa dalam melakukan pengutipan (Wicaksono \& Nurpratama, 2017). Penggunaan aplikasi Zotero menjadi pilihan bagi mahasiswa untuk meningkatkan pengetahuan dan keterampilan dalam mengelola referensi karya ilmiah (Habibah et al., 2018). Dari ketiga hasil penelitian yang telah dikemukakan, masih terdapat beberapa hal yang belum diteliti, seperti faktor pendukung dan penghambat, serta bagaimana mengoptimalisasikan aplikasi Zotero dalam penulisan karya ilmiah oleh mahasiswa. Berdasarkan hal tersebut, maka penelitian bertujuan untuk menganalisis pemanfaatan, faktor penghambat dan pendukung, serta upaya optimalisasi aplikasi Zotero dalam mengelola referensi karya tulis ilmiah mahasiswa Program Studi Pendidikan Bahasa dan Sastra Indonesia, Jurusan Bahasa dan Sastra Indonesia, Fakultas Bahasa dan Sastra (FBS), Universitas Negeri Makassar (UNM). 


\section{METODE}

Penelitian menggunakan pendekatan kualitatif dan dilakukan pada mahasiswa Program Studi Pendidikan Bahasa dan Sastra Indonesia, Jurusan Bahasa dan Sastra Indonesia, FBS UNM. Populasi penelitian adalah mahasiswa semester IV yang terdiri dari 3 kelas, yakni kelas 01, 02, dan 03. Adapun yang dijadikan sampel penelitian adalah kelas 03 dengan jumlah 40 orang mahasiswa. Pengambilan sampel menggunakan teknik purposive. Pemilihan mahasiswa semester IV sebagai populasi penelitian karena mahasiswa memprogramkan mata kuliah Menulis Karya Ilmiah di semester IV. Penelitian dilakukan pada proses pembelajaran menulis karya ilmiah dengan menggunakan aplikasi Zotero yang disusun dalam empat pertemuan.

Mata kuliah Menulis Karya Ilmiah berbobot 3 SKS dengan durasi setiap pertemuan adalah 150 menit. Pertemuan pertama, pembelajaran berfokus pada pendalaman materi, mengenai: teknik penulisan makalah; cara menyusun kerangka penulisan makalah dan pengembangannya; aturan-aturan penulisan; mengelola referensi; serta aturan penulisan daftar pustaka. Pertemuan kedua, pembelajaran berfokus pada pendalaman materi dan pelatihan penggunaan aplikasi Zotero. Pelatihan penggunaan aplikasi Zotero dilakukan dengan pemberian materi dan selanjutnya dipraktikkan secara bersama-sama. Pertemuan ketiga, pembelajaran berfokus pada praktik memanajemen referensi penulisan dan menulis makalah (karya tulis ilmiah) yang sesuai dengan kerangka penulisan yang telah dibuat pada pertemuan pertama. Pertemuan keempat, pembelajaran berfokus pada praktik memeriksa makalah sejawat. Pemeriksaan makalah berkisar pada format makalah, penggunaan rujukan ilmiah pada isi makalah, dan penulisan daftar pustaka yang menggunakan aplikasi Zotero.

Hasil menulis makalah mahasiswa, selanjutnya dinilai oleh dosen pengampu. Adapun kriteria hasil penilaian dosen, yaitu identitas makalah, sistematika makalah, teks utama makalah, dan daftar pustaka. Penilaian terkait dengan penggunaan aplikasi Zotero terletak pada teks utama makalah, yaitu pada penggunaan kutipan-kutipan pendapat para ahli atau hasil-hasil penelitian dan penulisan daftar pustaka. Skor menulis makalah yang diperoleh mahasiswa 
Edukasi: Jurnal Pendidikan, Volume 19 Nomor 1 Tahun 2021

Analisis Pemanfaatan, Faktor Pendukung dan Penghambat.......

Abdul Haliq, Akmal Hamsa, Sakaria

Halaman 16-30

selanjutnya dikonversi ke nilai huruf. Konversi skor ke nilai huruf terlihat pada Tabel 1 (UNM, 2019).

Tabel 1 Konversi Skor ke Nilai Huruf

\begin{tabular}{ccc}
\hline Rentang Skor & Nilai Huruf & Keterangan \\
\hline $91-100$ & A & Lulus \\
$86-90$ & A- & Lulus \\
$81-85$ & B+ & Lulus \\
$76-80$ & B & Lulus \\
$71-75$ & B- & Lulus \\
$66-70$ & C+ & Lulus \\
$61-65$ & C & Lulus \\
$56-60$ & C- & Tidak Lulus \\
$51-55$ & D+ & Tidak Lulus \\
$46-50$ & D & Tidak Lulus \\
$41-45$ & D- & Tidak Lulus \\
$41<$ & E & Tidak Lulus \\
\hline
\end{tabular}

Penelitian menggunakan human instrument (peneliti) yang bertugas untuk menetapkan fokus, memilih informan, serta melakukan pengumpulan data. Peneliti mengumpulkan data dengan teknik observasi, angket, dan wawancara. Teknik observasi digunakan untuk memperoleh data manfaat dan faktor pendukung penggunaan aplikasi Zotero. Adapun indikator pedoman observasi terlihat pada Tabel 2 .

Tabel 2 Indikator Pedoman Observasi

\begin{tabular}{ll}
\hline \multicolumn{1}{c}{ Aspek yang Dinilai } & \multicolumn{1}{c}{ Indikator } \\
\hline \multirow{2}{*}{$\begin{array}{l}\text { Penggunaan komputer/laptop dan } \\
\text { internet }\end{array}$} & Menggunakan komputer/laptop. \\
& Kemampuan mencari informasi di \\
& internet. \\
\hline \multirow{2}{*}{ Penggunaan aplikasi Zotero } & Mengoperasikan aplikasi Zotero. \\
& Menggunakan aplikasi Zotero dalam \\
& menulis ilmiah. \\
\hline
\end{tabular}

Angket digunakan untuk memperoleh data faktor penghambat dan wawancara digunakan untuk memperoleh data manfaat penggunaan aplikasi Zotero. Data yang terkumpul dianalisis dengan teknik analisis data interaktif, yaitu pengumpulan, reduksi, dan penyajian data, serta penarikan kesimpulan. Indikator angket terlihat pada Tabel 3 dan indikator pedoman wawancara terlihat pada Tabel 4. 
Tabel 3 Indikator Angket

\begin{tabular}{cl}
\hline \multicolumn{1}{c}{ Aspek yang dinilai } & \multicolumn{1}{c}{ Indikator } \\
\hline & Menggunakan aplikasi Zotero dalam \\
Penggunaan aplikasi Zotero & menulis ilmiah. \\
& Manfaat menggunakan aplikasi Zotero \\
& dalam menulis ilmiah. \\
\hline
\end{tabular}

Tabel 4 Indikator Pedoman Wawancara

\begin{tabular}{cl}
\hline \multicolumn{1}{c}{ Aspek yang Dinilai } & \multicolumn{1}{c}{ Indikator } \\
\hline Penggunaan aplikasi Zotero & Instalasi aplikasi Zotero. \\
& Mengoperasikan aplikasi Zotero. \\
\hline
\end{tabular}

\section{HASIL DAN PEMBAHASAN}

Pemanfaatan aplikasi Zotero dalam mengelola karya tulis ilmiah dilakukan dalam pembelajaran menulis makalah dan dilakukan selama empat pertemuan. Berdasarkan hasil penilaian makalah mahasiswa, diketahui bahwa mahasiswa telah terampil menggunakan aplikasi Zotero untuk kebutuhan mencari, menilai, mengumpulkan, melakukan sitasi, dan pengaturan referensi ilmiah. Hal tersebut terbukti dengan lulusnya mahasiswa pada mata kuliah Menulis Karya Ilmiah dengan nilai minimal B.

Tabel 5 Nilai Perolehan Menulis Karya Ilmiah

\begin{tabular}{cccc}
\hline Rentang Skor & Nilai Huruf & Frekuensi & Keterangan \\
\hline $91-100$ & A & 17 & Lulus \\
$86-90$ & A- & 13 & Lulus \\
$81-85$ & B+ & 7 & Lulus \\
$76-80$ & B & 3 & Lulus \\
\hline
\end{tabular}

Berdasarkan Tabel 5, dapat disimpulkan bahwa seluruh mahasiswa yang mengikuti perkuliahan menulis karya ilmiah dinyatakan lulus. Hal tersebut menunjukkan bahwa penggunaan aplikasi Zotero dapat meningkatkan kemampuan menulis karya ilmiah mahasiswa.

\section{Manfaat Penggunaan Aplikasi Zotero}

Aplikasi Zotero sangat bermanfaat dalam membantu mahasiswa dalam menulis karya ilmiah. Hal tersebut diungkapkan oleh mahasiswa melalui hasil 
Edukasi: Jurnal Pendidikan, Volume 19 Nomor 1 Tahun 2021

Analisis Pemanfaatan, Faktor Pendukung dan Penghambat.......

Abdul Haliq, Akmal Hamsa, Sakaria

Halaman 16-30

wawancara dan hasil pengamatan/observasi peneliti selama proses pembelajaran berlangsung. Manfaat yang diperoleh mahasiswa dalam menggunakan aplikasi Zotero, yaitu: (1) Kemudahan dalam mengelola referensi secara daring (online); (2) Mahasiswa memiliki perpustakaan digital; (3) Kemudahan melakukan sitasi tulisan atau artikel yang berkaitan dengan tulisan yang dikembangkan; dan (4) Efisiensi dalam pengelolaan tulisan ilmiah.

Manfaat yang pertama dari penggunaan aplikasi Zotero adalah kemudahan dalam mengelola referensi secara daring (online). Aplikasi Zotero dapat digunakan untuk mengelola berbagai sumber referensi secara otomatis ketika penulis memilih referensi dan menempatkannya di aplikasi pengolah kata (Ray \& Ramesh, 2017). Kemudahan pengelolaan informasi membuat makalah yang ditulis oleh mahasiswa lebih kaya akan informasi dan memiliki berbagai jenis sumber kutipan yang dapat ditambahkan ke makalah.

Manfaat yang kedua dari penggunaan aplikasi Zotero adalah mahasiswa memiliki perpustakaan digital. Pada aplikasi Zotero, dapat dibuat perpustakaan penelitian dan tersimpan pada situs web Zotero.org (Nuraini, 2020; Ray \& Ramesh, 2017). Aplikasi Zotero juga dapat digunakan untuk mendokumentasikan situs web, karya seni, film, rekaman suara, kasus hukum, dan video (Vaidhyanathan et al., 2012). Mahasiswa dapat mengatur perpustakaannya dalam aplikasi Zotero dengan menggunakan kata kunci tertentu, seperti judul, tahun, tema tulisan, dan lain sebagainya.

Manfaat yang ketiga dari penggunaan aplikasi Zotero adalah kemudahan melakukan sitasi tulisan atau artikel yang berkaitan dengan tulisan yang dikembangkan. Penulis dapat memanfaatkan aplikasi Zotero dalam menambahkan kutipan secara otomatis dengan menggunakan nomor ISBN, Digital Object Identifier (DOI), atau ID PubMed (Vaidhyanathan et al., 2012). Aplikasi Zotero yang telah terintegrasi dengan Microsoft Word dapat secara otomatis membuat daftar pustaka berdasarkan artikel atau buku yang dikutip dalam tulisan (Wicaksono \& Nurpratama, 2017).

Manfaat yang keempat dari penggunaan aplikasi Zotero adalah efisiensi dalam pengelolaan tulisan ilmiah. Penulis dapat meningkatkan efisiensi dengan 
menggunakan aplikasi Zotero untuk membantu dalam mengelola, mengatur, dan mencari artikel yang dapat digunakan dalam menulis (Vaidhyanathan et al., 2012). Penggunaan aplikasi Zotero juga meningkatkan kualitas dan hasil pembelajaran. Hal tersebut terlihat pada meningkatnya hasil belajar mahasiswa pada mata kuliah Menulis Karya Ilmiah dengan tingkat persentase kelulusan mencapai $100 \%$. Aplikasi Zotero memberi kemudahan bagi mahasiswa dalam mengelola tulisan akademik maupun nonakademik (Anjali \& Istiqomah, 2020; Wicaksono \& Nurpratama, 2017).

\section{Faktor Penghambat dan Pendukung Penggunaan Aplikasi Zotero}

Pelaksanaan pembelajaran menulis karya ilmiah makalah dengan pemanfaatan aplikasi Zotero dalam mengelola referensi ditemukan beberapa faktor penghambat dan pendukungnya. Data faktor penghambat diperoleh dari hasil angket yang telah diisi oleh mahasiswa. Sedangkan, data faktor pendukung diperoleh dari hasil observasi pelaksanaan pembelajaran.

Faktor penghambat pemanfaatan aplikasi Zotero dalam mengelola referensi penulisan makalah, yaitu: (1) Mahasiswa tidak terbiasa menggunakan aplikasi Zotero; (2) Menginstal aplikasi Zotero; (3) Menyinkronkan file pada aplikasi Zotero; (4) Mengintegrasikan aplikasi Zotero dengan aplikasi pengolah kata; dan (5) Menambahkan sitasi pada aplikasi Microsoft Word. Berbagai kendala tersebut dapat terselesaikan dengan bantuan dosen dan berbagai media yang digunakan seperti buku panduan, video tutorial, dan WhatsApp group.

Mahasiswa menyatakan belum terbiasa menggunakan aplikasi Zotero dalam penulisan makalah. Dalam melakukan sitasi referensi maupun menyusun daftar pustaka, mahasiswa belum pernah menggunakan alat bantu pengelola referensi atau dikerjakan secara manual. Pengerjaan secara manual dapat menyebabkan tindakan plagiarisme yang mungkin terjadi karena penulisan tidak disertai dengan sumber atau sumber tidak dituliskan dalam daftar pustaka. Tindakan plagiarisme biasanya terjadi karena mahasiswa tidak mengetahui cara menelusuri sumber kutipan dan tidak mengetahui teknik mengutip sumber online ataupun sumber lain (Prihantini \& Indudewi, 2017). 
Edukasi: Jurnal Pendidikan, Volume 19 Nomor 1 Tahun 2021

Analisis Pemanfaatan, Faktor Pendukung dan Penghambat.......

Abdul Haliq, Akmal Hamsa, Sakaria

Halaman 16-30

Aplikasi Zotero dapat diinstal pada perangkat komputer dengan versi standalone. Kebanyakan mahasiswa mengalami kendala pada proses instalasi. Aplikasi Zotero yang terinstal tidak terkoneksi dengan peramban yang digunakan (Chrome, Safari, Firefox). Sehingga, mahasiswa tidak dapat melakukan penelusuran referensi secara online pada website penyedia referensi digital. Aplikasi Zotero membutuhkan perangkat tambahan berupa konektor yang diinstal secara terpisah pada peramban (Chrome, Safari, Firefox). Hal tersebut menjadi penyebab aplikasi Zotero tidak terkoneksi dengan perangkat peramban. Aplikasi Zotero dapat terkoneksi dengan peramban versi terbaru. Google merilis update versi Chrome 83.0.4103.116 pada tahun 2020 yang dapat diunduh pada laman https://www.google.co.id/chrome. Selanjutnya, Safari merilis update versi Safari 5.1.7 yang dapat diunduh pada laman https://safari_for_windows.id. downloadastro.com. Sedangkan, versi terbaru Firefox adalah 72.0.2 yang dapat diunduh pada laman https://www.mozilla.org/id/firefox/new. Mahasiswa yang belum memiliki peramban versi update terbaru pada perangkat komputer, tidak dapat melakukan penelusuran literatur secara online.

Sinkronisasi file referensi berupa buku atau artikel pada aplikasi Zotero dilakukan dengan menggunakan fasilitas Zotero file storage atau WebDAV. Sinkronisasi file dapat mempermudah penulis menemukan data yang dicari untuk digunakan atau dikutip dalam tulisan yang dibuat. Namun, pada praktik sinkronisasi tersebut, rata-rata mahasiswa mengalami kendala pada koneksi verify server. Sehingga, data yang diakses secara online tidak terbaca pada metadata aplikasi Zotero yang terinstal pada komputer.

Kendala lain yang dihadapi mahasiswa yaitu tidak sinkronnya aplikasi pengolah kata (Microsoft Word) yang digunakan oleh mahasiswa dengan aplikasi Zotero. Hal tersebut terjadi karena versi Microsoft Word yang digunakan oleh mahasiswa belum secara otomatis tersinkron dengan aplikasi Zotero. Sebagian besar mahasiswa menggunakan Microsoft Word versi 2010 pada perangkat komputer. Pada Microsoft Word versi 2010, aplikasi Zotero tidak secara otomatis tersinkron, akan tetapi terlebih dahulu harus mengaktifkan fungsi developer pada fitur coztomize ribbon. Sehingga, rata-rata mahasiswa menyatakan terkendala 
dalam melakukan sinkronisasi aplikasi Zotero dengan Microsoft Word 2010. Sedangkan, bagi mahasiswa yang menggunakan Microsoft Word versi 2007, Zotero akan secara otomatis tersinkron apabila aplikasi telah diinstal ke komputer. Berdasarkan hasil wawancara, mahasiswa ada yang menggunakan Microsoft Word versi 2007 dan ada juga yang menggunakan versi 2010.

Kendala yang juga dialami oleh mahasiswa adalah sitasi referensi dari sumber-sumber yang ilmiah dan relevan (book, book section, atau journal article). Menambahkan sitasi penulisan makalah dilakukan dengan memindahkan metadata pada aplikasi Zotero. Aplikasi Zotero dapat membuat daftar referensi dengan mudah (Ray \& Ramesh, 2017) dan sesuai dengan model penulisan referensi (citation style) yang umumnya digunakan dalam penulisan karya ilmiah. Berdasarkan selingkung yang digunakan oleh Jurusan Bahasa dan Sastra Indonesia FBS UNM sebagai dasar dalam membuat makalah, model citation style yang disepakati adalah American Psychological Association (APA) 7th Edition. Citation style yang digunakan oleh mahasiswa masih berbeda-beda. Hal tersebut terjadi karena mahasiswa tidak melakukan pengaturan citation style.

Berdasarkan hasil penelitian, faktor pendukung pemanfaatan aplikasi Zotero dalam mengelola referensi penulisan karya ilmiah, yaitu: (1) Keterampilan yang dimiliki mahasiswa dalam mengoperasikan perangkat komputer/laptop; (2) Penguasaan mahasiswa mengenai teknik penulisan makalah; (3) Aplikasi Zotero bersifat nonkomersial; (4) Metadata mudah untuk disimpan; (5) Konversi metadata menjadi kutipan atau daftar pustaka mudah dilakukan; dan (6) Metadata mudah untuk diedit. Penggunaan aplikasi Zotero dalam manajemen referensi penulisan karya ilmiah membutuhkan keterampilan untuk mengoperasikan perangkat komputer. Mahasiswa telah menguasai pengoperasian perangkat komputer, sehingga keterampilan yang dimiliki tersebut dapat mendukung penggunaan aplikasi Zotero.

\section{Optimalisasi Penggunaan Aplikasi Zotero}

Upaya optimalisasi pemanfaatan aplikasi Zotero dalam mengelola referensi penulisan karya ilmiah dilakukan oleh dosen pengampu mata kuliah dengan 
Edukasi: Jurnal Pendidikan, Volume 19 Nomor 1 Tahun 2021

Analisis Pemanfaatan, Faktor Pendukung dan Penghambat.......

Abdul Haliq, Akmal Hamsa, Sakaria

Halaman 16-30

menyediakan beberapa fasilitas pendukung pembelajaran, yaitu: (1) Buku panduan aplikasi Zotero; (2) Video tutorial pengunanan aplikasi Zotero; (3) Buku panduan sitasi; dan (4) WhatsApp group. Buku panduan aplikasi Zotero bertujuan sebagai pegangan dan sumber acuan mahasiswa untuk mengoperasikan fitur-fitur pada aplikasi Zotero. Buku panduan memuat: petunjuk teknis yang disertai dengan gambar untuk menginstal aplikasi Zotero; sinkronisasi file; membangun pangkalan data; membuat new collection data; mencari dan menemukan koleksi referensi; integrasi dengan aplikasi pengolah kata; menambahkan sitasi ke dalam Microsoft Word; mengubah citation style; serta membuat daftar pustaka. Buku panduan dapat diunduh melalui laman http://gg.gg/bukupanduan-com.

Muatan materi pada video tutorial hampir sama dengan yang terdapat dalam buku panduan aplikasi Zotero. Akan tetapi, pada video tutorial berisi petunjuk teknis dalam bentuk audio visual. Video tutorial tersebut disajikan dalam bentuk rekaman video dan penjelasan dalam bentuk suara setiap langkah-langkah pengoperasian fitur-fitur pada aplikasi Zotero. Video tutorial dapat diunduh melalui laman http://gg.gg/videotutorial-com. Disediakan juga buku panduan sitasi sebagai pegangan mahasiswa untuk melakukan sitasi referensi penulisan karya ilmiah. Buku panduan memuat teknik menuliskan sitasi dan format penulisan daftar pustaka berdasarkan jenis referensi atau sumber ilmiah yang digunakan. Buku panduan dapat diunduh melalui laman http://gg.gg/panduansitasi-com. Fasilitas selanjutnya yang dapat digunakan oleh mahasiswa yaitu WhatsApp group. Fasilitas tersebut digunakan sebagai sarana komunikasi dosen pengampu mata kuliah dengan mahasiswa di luar jam perkuliahan untuk mengatasi kendala-kendala yang dihadapi dalam mengoperasikan aplikasi Zotero.

\section{SIMPULAN}

Hasil penelitian menunjukkan bahwa pemanfaatan aplikasi Zotero memudahkan mahasiswa mengelola referensi, memiliki perpustakaan digital, dan kemudahan sitasi tulisan. Adapun faktor penghambat, yaitu mahasiswa tidak terbiasa menggunakan aplikasi, proses instalasi, sinkronisasi file, integrasi, dan 
penambahan sitasi dengan Microsoft Word. Sedangkan faktor pendukung, yaitu keterampilan mengoperasikan komputer, penguasaan teknik penulisan makalah, aplikasi Zotero bersifat nonkomersial, kemudahan menyimpan, mengonversi, dan mengedit metadata. Upaya optimalisasi dilakukan dengan memberikan fasilitas pendukung seperti buku panduan dan video tutorial, buku panduan sitasi, serta WhatsApp group. Berdasarkan hasil penelitian yang diperoleh tersebut, dapat disimpulkan bahwa penggunaan aplikasi Zotero dapat meningkatkan kemampuan mahasiswa menulis karya ilmiah, khususnya dalam mencari, mengumpulkan, melakukan sitasi referensi online, dan menulis referensi secara otomatis.

\section{DAFTAR PUSTAKA}

Aidid, M. K., Bustan, M. N., \& Statistika, P. (2020). Manajemen referensi dengan aplikasi Zotero. Jurnal Dedikasi, 22(2), 126-128.

Anjali, M. E. C., \& Istiqomah, Z. (2020). Implementasi pelatihan aplikasi Zotero di perpustakaan Universitas Muhammadiyah Yogyakarta bagi mahasiswa magister Ilmu Pemerintahan. Publication Library and Information Science, 3(2), 97-103. http://dx.doi.org/10.24269/pls.v3i2.2434.

Courraud, J. (2014). Zotero: A free and open-source reference manager. Medical Writing, 23(1), 46-48. https://doi.org/10.1179/2047480614Z.000000000190.

Habibah, S., Basri, S., \& Mus, S. (2018). Manajemen referensi penulisan karya tulis ilmiah Mahasiswa STKIP-PI Makassar. Seminar Nasional Lembaga Pengabdian kepada Masyarakat UNM Tahun 2018.

Haliq, A., \& Riyanti, A. (2018). Pembelajaran mandiri melalui literasi digital. Seminar Tahunan Linguistik Tingkat Internasional SPs UPI Tahun 2018.

Idri, N. (2015). Zotero software: A means of bibliographic research and data organisation; teaching bibliographic research. Arab World English Journal, $\operatorname{July}(2), 124-133$.

Kurniadi, F. (2017). Penulisan karya tulis ilmiah mahasiswa dengan media aplikasi pengolah kata. Aksis: Jurnal Pendidikan Bahasa dan Sastra Indonesia, 1(2), 267-277. https://doi.org/10.21009/AKSIS.010208. 
Edukasi: Jurnal Pendidikan, Volume 19 Nomor 1 Tahun 2021

Analisis Pemanfaatan, Faktor Pendukung dan Penghambat.......

Abdul Haliq, Akmal Hamsa, Sakaria

Halaman 16-30

Mansyur, U. (2016). Inovasi pembelajaran Bahasa Indonesia melalui pendekatan proses. Jurnal Retorika, 9(2), 90-163. https://doi.org/10.26858/retorika. v9i2.3806.

Marshall, C. (2020). Citation management software raises library profile. Journal of Hospital Librarianship, 20(2), 151-155. https://doi.org/10.1080/ 15323269.2020.1738850.

Maryatun. (2020). Efektivitas kegiatan literasi digital dalam meningkatkan kemampuan penulisan karya ilmiah bagi mahasiswa. Fihris: Jurnal Ilmu Perpustakaan dan Informasi, 15(2), 145-166. https://doi.org/10.14421/ fhrs.2020.152.145-166.

Mauludin, S., \& Cahyani, I. (2018). Literasi digital dalam pembelajaran menulis. Seminar International Riksa Bahasa XII Prodi Pendidikan Bahasa Indonesia SPs UPI Tahun 2018.

Nuraini, M. W. (2020). Analisis perbandingan aplikasi manajemen referensi Zotero 5.0.66. dan Endnote X9. Publication Library and Information Science, 3(2), 80-86. http://dx.doi.org/10.24269/pls.v3i2.2112.

Pecorari, D. (2013). Teaching to avoid plagiarism: How to promote good source use. Berkshire, England: Open University Press.

Prihantini, F. N., \& Indudewi, D. (2017). Kesadaran dan perilaku plagiarisme di kalangan mahasiswa (Studi pada mahasiswa Fakultas Ekonomi Jurusan Akuntansi Universitas Semarang). Jurnal Dinamika Sosial Budaya, 18(1), 68-75. https://doi.org/10.26623/jdsb.v18i1.559.

Ray, A. K., \& Ramesh, D. B. (2017). Zotero: Open source citation management tool for researchers. International Journal of Library and Information Studies, 7(3), 238-245.

Supriyanto, W., \& Iswandari, R. (2017). Kecenderungan sivitas akademika dalam memilih sumber referensi untuk penyusunan karya tulis ilmiah di perguruan tinggi. Berkala Ilmu Perpustakaan dan Informasi, 13(1), 79-86. https://doi.org/10.22146/bip.26074.

Supriyatno, H. (2018). Pemanfaatan Zotero dalam penyusunan karya tulis ilmiah pustakawan. Indonesian Journal of Academic Librarianship, 1(2), 39-53. 
Thomas, A. (2017). Faculty reluctance to report student plagiarism: a case study. African Journal of Business Ethics, 11(1), 103-119. https://doi.org/ 10.15249/11-1-148.

Universitas Negeri Makassar (UNM). (2019). Peraturan Rektor Universitas Negeri Makassar tentang Peraturan Akademik Universitas Negeri Makassar. Makassar: Universitas Negeri Makassar.

Vaidhyanathan, V., Moore, M., Loper, K. A., Van-Schaik, J., \& Goolabsingh, D. (2012). Making bibliographic researchers more efficient: Tools for organizing and downloading pdfs, part 1: Icyte, Mendeley Desktop, Papers, PDF Stacks, PubGet Paperplane, WizFolio, and Zotero. Journal of Electronic Resources in Medical Libraries, 9(1), 47-55. https://doi.org/10.1080/15424065.2012.651576.

Wicaksono, M. F., \& Nurpratama, M. R. (2017). Benefits of record management for scientific writing (Study of metadata reception of Zotero reference management software in UIN Malang). Record and Library Journal, 3(2), 209-219. http://dx.doi.org/10.20473/rlj.V3-I2.2017.209-219.

Winslow, R. R., Skripsky, S. L., \& Kelly, S. L. (2016). Chapter 14. Not just for citations: Assessing Zotero While reassessing research. In B. J. D’Angelo, S. Jamieson, B. Maid, \& J. R. Walker (Eds.), Information Literacy: Research and Collaboration across Disciplines (pp. 287-304). The WAC Clearinghouse: University Press of Colorado. 